\title{
Nattokinase: An Oral Antithrombotic Agent for the Prevention of Cardiovascular Disease
}

\author{
Yunqi Weng ${ }^{1}$, Jian Yao ${ }^{1}$, Sawyer Sparks ${ }^{2}$ and Kevin Yueju Wang ${ }^{2, *}$ \\ 1 Emergency Department, The Affiliated Hospital of Qingdao University, Qingdao 266005, China; \\ wengyunqi@126.com (Y.W.); yaojian2002@126.com (J.Y.) \\ 2 Department of Natural Sciences, Northeastern State University at Broken Arrow, Broken Arrow, OK 74014, \\ USA; sparks07@nsuok.edu \\ * Correspondence: wang03@nsuok.edu; Tel.: +1-918-449-6479; Fax: +1-918-449-6473
}

Academic Editor: David Arráez-Román

Received: 24 January 2017; Accepted: 26 February 2017; Published: 28 February 2017

\begin{abstract}
Natto, a fermented soybean product, has been consumed as a traditional food in Japan for thousands of years. Nattokinase (NK), a potent blood-clot dissolving protein used for the treatment of cardiovascular diseases, is produced by the bacterium Bacillus subtilis during the fermentation of soybeans to produce Natto. NK has been extensively studied in Japan, Korea, and China. Recently, the fibrinolytic (anti-clotting) capacity of NK has been recognized by Western medicine. The National Science Foundation in the United States has investigated and evaluated the safety of NK. NK is currently undergoing a clinical trial study (Phase II) in the USA for atherothrombotic prevention. Multiple NK genes have been cloned, characterized, and produced in various expression system studies. Recombinant technology represents a promising approach for the production of NK with high purity for its use in antithrombotic applications. This review covers the history, benefit, safety, and production of NK. Opportunities for utilizing plant systems for the large-scale production of NK, or for the production of edible plants that can be used to provide oral delivery of NK without extraction and purification are also discussed.
\end{abstract}

Keywords: nattokinase; oral; antithrombotic agent; cardiovascular disease; plant molecular farming; gene expression

\section{Introduction}

Nattokinase (NK) is not related to any of the known kinases. NK is a serine protease purified and extracted from natto (Figure 1A), a traditional Japanese food produced from the fermentation of soybeans with the bacterium, Bacillus subtilis (natto) (Figure 1B,C). Natto is regarded as a fibrinolytic miracle food (Figure 2). In 1980, Hiroyuki Sumi, a Japanese researcher at the Chicago University Medical School, discovered that natto can dissolve artificial fibrin [1]. Sumi and his team extracted an enzyme from natto that not only degraded fibrin but also a plasmin substrate. He named this novel, fibrinolytic enzyme "nattokinase" [1].

NK can break down blood clots by directly hydrolyzing fibrin and plasmin substrate, converts endogenous prourokinase to urokinase (uPA), degrades PAI-1 (plasminogen activator inhibitor-1), and increases tissue plasminogen activator (t-PA) which supports fibrinolytic activity (Figure 3: Mechanism of action) [2]. Unlike common fibrinolytic proteases, such as t-PA and uPA, which can produce various side effects such as bleeding, NK exhibits little to no side effects. Studies also indicate that an oral administration of NK can be absorbed by the intestinal tract $[3,4]$. NK exhibits strong fibrinolytic activity after intraduodenal absorption. These characteristics make NK a versatile and potent fibrinolytic enzyme that can be used to combat blood clots. 


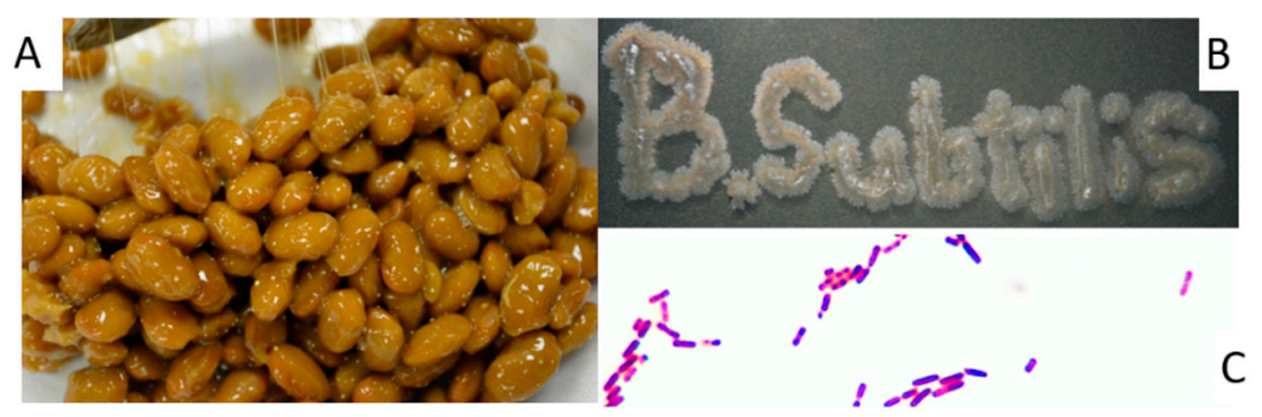

Figure 1. Natto-a traditional Japanese food produced from soybeans fermented by Bacillus subtilis (natto). (A) Natto-Fermented Soy Beans; (B) B. subtilis (natto) isolated from natto; (C) Micrograph of gram stained cells of B. subtilis (natto) $(1000 \times)$.

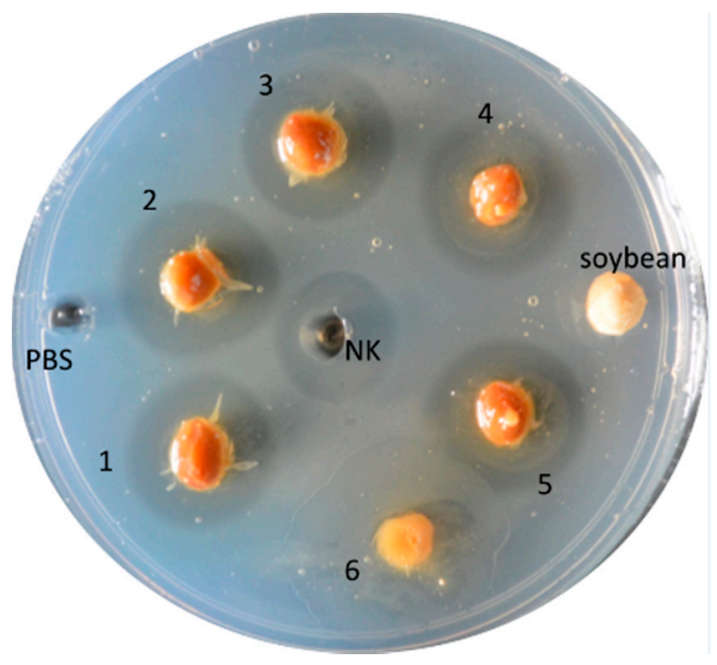

Figure 2. Natto and nattokinase can dissolve fibrin (semi-transparent halo ring). (1-5) Natto-fermented soy beans; (6) Slimy material characteristic of natto; (NK) Commercial nattokinase (100 $\mu \mathrm{g}$ ) as a positive control; Non-fermented soybean and PBS (phosphate buffered saline) as negative controls.

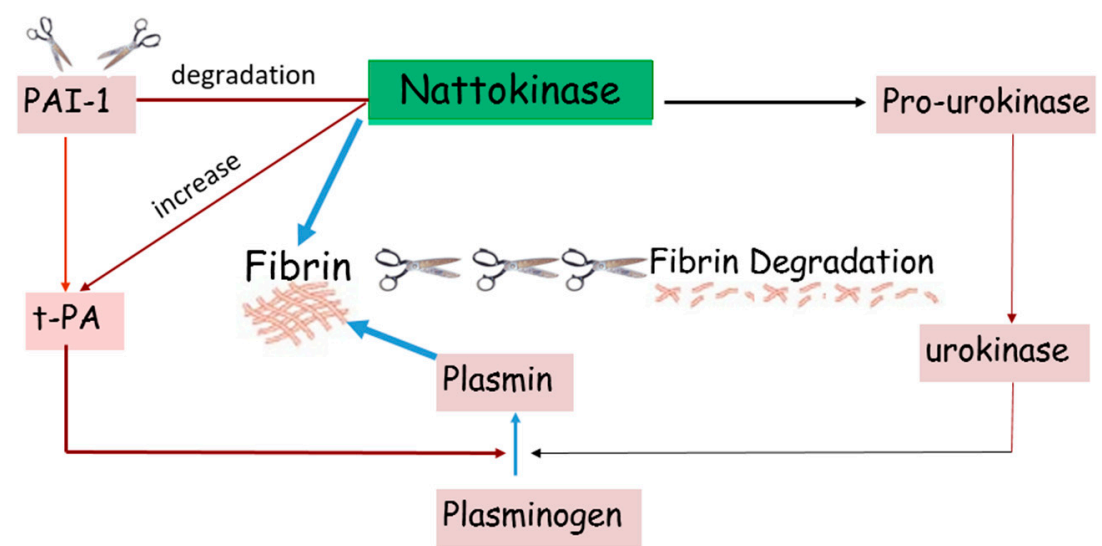

Figure 3. Mechanism of Action. Nattokinase dissolves blood clots by directly hydrolyzing fibrin and plasmin substrate. It converts endogenous prourokinase to urokinase (uPA). It also degrades plasminogen activator inhibitor (PAI-1) and increases the level of tissue plasminogen activator (t-PA). 


\section{Benefits of Nattokinase}

Nattokinase is considered to be a safe, powerful, low cost, and all-natural supplement for the treatment of heart and cardiovascular disease [5-7]. Animal [3,4,8] and human trials [9-11] have demonstrated that NK provides support to the circulatory system by thinning the blood and dissolving blood clots. When dogs were orally administered four NK capsules (2000 FU/capsule), chemically-induced thrombi in the major leg vein were completely dissolved within five hours and normal blood flood was restored [8]. A rat model of thrombosis in the common carotid artery also demonstrated that NK-treated rats recovered $62 \%$ of arterial blood flow. NK exhibited considerably stronger thrombolytic activity than the fibrinogenolytic and fibrinolytic enzymes, plasmin, or elastase; which restored $15 \%$ and $0 \%$ of blood blow in the rat carotid artery, respectively [3].

NK was reported to have an effect on both oxidative injury-mediated arterial thrombosis $[12,13]$ and inflammation-induced venal thrombosis [14]. When ferric chloride $\left(\mathrm{FeCl}_{3}\right)$ was administered to the injured arteries, it resulted in oxidative thrombosis and platelet adhesion. After treatment with NK, however, thrombus formation and platelet aggregation were inhibited. The effects of NK are similar to the well-known blood thinner, aspirin [13]. Unlike aspirin, which often triggers bleeding or gastric ulcers, NK improves blood flow without any adverse effects. $\mathrm{k}$-Carrageenan-induced inflammatory thrombi formation in rat tails was used to examine the effect of NK [14]. Twelve hours after gavage administration of NK, higher levels of fibrin degradation product (FDP) fragments and D-dimers were detected in blood samples. A greater than $50 \%$ decrease in thrombosis was observed in the blood vessels of the rat tail by biopsy analysis.

Elevated levels of factor VII and VIII are associated with greater risk of cardiovascular disease due to the potential of these factors to trigger a blood coagulation cascade. In a human trial, three groups (healthy volunteers, patients with cardiovascular risk factors, and patients undergoing dialysis) were orally administered two capsules of NK (2000 FU/capsule) on a daily basis. After two months, a significant and similar decrease in factor VII, factor VIII, and fibrinogen was observed in all of the groups. No adverse effects were detected during the two-month trial and heart rate, body weight, and uric acid levels remained stable [15].

Nattokinase has a strong ability to breakdown thrombi and fibrin. Even a single dose of NK has been reported to result in fibrinolysis via the cleavage of cross-linked fibrin [10]. In that study, 12 healthy, young males were randomly administered a single capsule of NK (2000 FU). The antithrombin concentration in their blood increased significantly two hours after the oral consumption of the NK capsule. FDP fragments and D-dimers were observed four and six hours after NK administration, respectively, and factor VIII activity declined four hours after NK ingestion. The results of this study indicated that multiple different pathways may be involved in NK fibrinolysis and anti-coagulation activity.

Both NK and lumbrokinase (derived from earthworms), unlike most proteins, are more resistant to the highly acidic gastric fluids in the stomach and can be absorbed in the later sections of the digestive tract. In 1995, Fujita and colleagues demonstrated that NK could be absorbed from the rat intestinal tract in an intact form and degraded fibrinogen in plasma blood samples [3]. Subsequently, in 2013, a research team in the United States detected intact NK in the serum of healthy humans after they were administrated a single, oral dose of NK (2000 FU /100 mg) in a capsule [16]. Other studies have also shown that oral administration of NK can enhance fibrinolytic activity in plasma $[3,16]$. The mechanism by which NK is transported from the digestive tract into the circulatory system still needs to be elucidated. $\mathrm{NK}$ can resist high temperature $\left(50^{\circ} \mathrm{C}\right.$ ) and $\mathrm{pH}$ (to 10), which certainly contributes to the ability of this enzyme to remain intact in the gastrointestinal tract [6].

At present, commercial NK products (Figure 4) are widely-used in Japan, China, Korea, European Union Countries, Canada, and the United States as a food supplement to thin blood, prevent blood clots, and improve blood circulation. Studies also indicate that NK can ameliorate other diseases such as hypertension [4], stroke [17], Alzheimer's disease [18], and atherosclerosis [19]. The potential of using NK to decrease atherothrombotic risk and slow the progression of atherosclerosis as well as 
cognitive decline is currently being assessed in a Phase II clinical trial (ClinicalTrials.gov Identifier: NCT02080520, 28 May 2015).

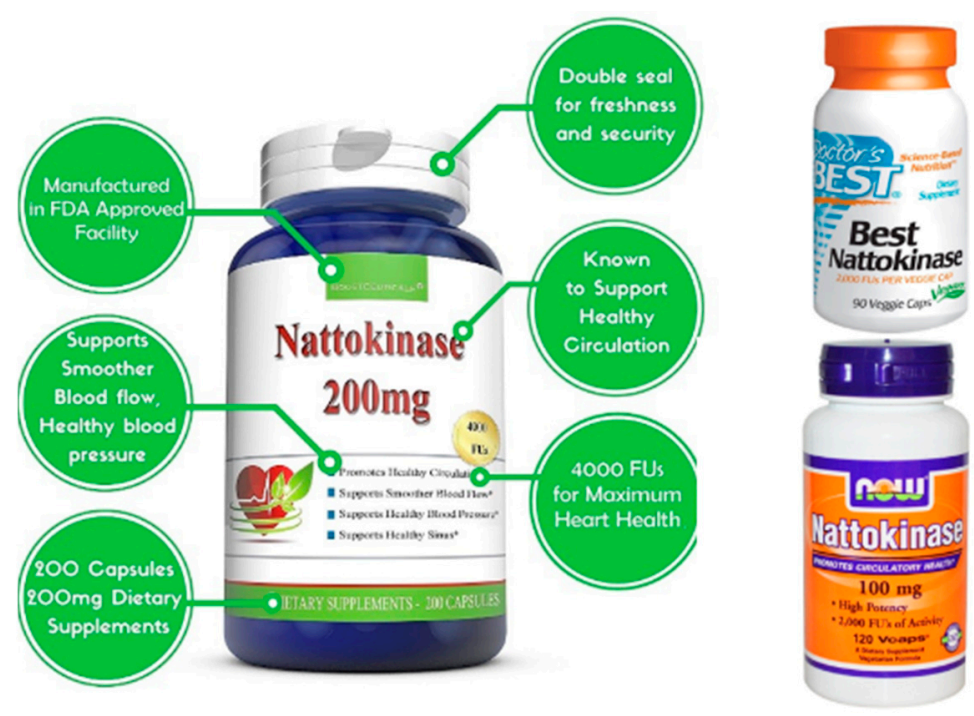

Figure 4. Nattokinase products (Pictures obtained from company websites).

\section{Nattokinase Safety Assessment}

Natto (Figure 1A), a soybean product fermented by the bacterium, Bacillus subtilis (natto), has been consumed as a traditional food in Japan for over a thousand years. Reports have suggested that natto contributes significantly to the longevity of Japanese people [1,5]. The accumulation of lipofusin (age pigment) is considered a hallmark of aging. In this regard, natto extract was reported to delay lipofusin accumulation in the nematode, Caenorhabditis elegans. The lifespan of $C$. elegans was also significantly prolonged by the Natto extract [20].

Although no adverse sides effects have been observed from the consumption of NK in various human trials, including clinical trials, the safety profile for NK, including the effect of repeat doses, acute toxicity, and genotoxicity, still needs to be thoroughly addressed. Comprehensive safety data, assembled under Good Laboratory Practice (GLP)-compliant studies and reported in 2016, indicated that neither clastogenic nor mutagenic activity was observed in vitro after NK treatment [11].

B. subtilis (Figure 1B,C), the bacterium responsible for the production of natto and the synthesis of $\mathrm{NK}$, is not a pathogenic bacterium. The inoculation of rats with $B$. subtilis $\left(1.51 \times 10^{9} \mathrm{CFU} / \mathrm{mL}\right)$ derived from natto did not produce any signs of toxicity. Fourteen days after the treatment, no remaining viable B. subtilis cells were observed in the lungs, liver, brain, or kidneys by histopathological examination. No significant adverse signs or mortality were observed in an acute toxicity study within a 14-day study period when rats were gavage administrated a single dose of NK $(2000 \mathrm{mg} / \mathrm{kg})$. When rats were repetitively given single daily dose of NK $(1000 \mathrm{mg} / \mathrm{kg})$ for 90 days, no abnormal clinical observations were detected relative to control groups.

In human clinical studies, no-adverse-effect-level (NOAEL) was found when healthy human volunteers orally consumed NK $(10 \mathrm{mg} / \mathrm{kg})$ daily for 28 days [11]. Participants in the study exhibited no significant changes in their urine, blood pressure, or pulse. The collective data found in toxicity studies has provided a robust safety assessment for NK usage to both regulatory agencies and pharmaceutical companies. Presently, the recommended usage for NK is for two capsules (100 mg/capsule) daily. This dosage of NK has raised very low toxicological concerns based on the previously published safety studies. 


\section{Production and Purification of Nattokinase}

The fermented soybean product, natto, is the main source for obtaining purified NK. A similar enzyme has been extracted from other fermented soybean-based foods, such as Thai thua nao [21], Chinese douchi [22], and Korean doen-jang [23].

The traditional process of fermenting soybeans to make natto is simple and straightforward, and can be easily done at home. Bacillus subtilis (natto) is the starter used to make natto, commercially and at home. B. subtilis (natto) can maintain activity at a $\mathrm{pH}$ of 6-12 and resist high temperatures up to $60{ }^{\circ} \mathrm{C}[24,25]$. The B. subtilis strains present in current commercial NK products can maintain viability and metabolic activity at room temperature for at least six months. Cooked soybeans are inoculated with B. subtilis (natto) and incubated at room temperature to ferment for at least $24 \mathrm{~h}$ until the beans are covered with a viscous and sticky substance produced by the bacterium and consisting of glutamic acid polymers (Figure 1A). Commercial NK production practices optimize the fermentation conditions to maximize the yield of NK produced by B. subtilis (natto), and include optimal temperature, $\mathrm{pH}$, and fermentation time [26,27]. A variety of nutrients, such as glycerol, yeast extract, soy peptone, or shrimp shell powder have been examined for their ability to increase NK yield [28-30]. The optimal feed strategy used in in fed-batch fermentation methods has significantly enhanced NK production, relative to yields obtained by batch fermentation [31].

Compared to the simple fermentation process, downstream extraction and purification of NK from natto slurry is difficult and inefficient. Several steps are required, including homogenization with an organic solvent, salting out the proteins, protein ion-exchange chromatography and dialysis, etc. Low NK activity recovery from these involved processes have driven researchers to investigate more inexpensive, rapid, and efficient techniques for NK purification [24,32,33]. Garg and Thorat [34] developed a three phase partitioning (TPP) technique to purify NK by combining t-butanol $(1.5 \times$ to crude extract) and ammonium sulphate $(30 \% w / v)$ to precipitate the NK protein. The desired results were obtained using an optimal $\mathrm{pH}(8.0)$ and temperature $\left(37^{\circ} \mathrm{C}\right)$. NK activity varies, however, when different purification methods are used. In addition, there is also potential for the retention of excessive byproducts in the final product than can cause an allergenic reaction [35].

The mild odor and stringy texture of natto is a major drawback to its use as a common food. Outside of Japan, NK is generally consumed orally in capsules typically made of vegetable-based materials for vegetarians. The presence of impurities in current NK products, however, prevents their common use as therapeutic medicine for thrombosis. Current NK products have raised concerns in the Federal Drug Administration (FDA) due to the requirement of high-levels of purity in single component entities. Thus, recombinant technologies have been explored to increase the quantities and purity of the NK being produced.

\section{Analysis of the Nattokinase Gene and Protein}

Nattokinase is encoded by the aprN gene, which was first cloned and sequenced from B. subtilis (natto) [36]. The full length polypeptide contains a 29-residue signal peptide which directs protein secretion through the cell membrane, and a 77-residue propeptide which plays a crucial role as an intramolecular chaperone during the protein folding process; resulting in a 275-residue, mature and functional NK peptide. The partial length of $a p r N$ gene is $0.8 \mathrm{~kb}$ in length (Figure $5 \mathrm{~A}$ ) and the mature peptide has a molecular weight of $27.7 \mathrm{kDa}$ (Figure $5 \mathrm{~B}$ ). Since the amino acid sequence of NK is almost identical (99.3\% homologous) to Subtilisin E, NK was also considered as a member of the subtilisin serine protease family. Unlike subtilisin, however, NK has a very specific affinity for fibrin degradation [37]. The $\mathrm{D}^{32}-\mathrm{H}^{64}-\mathrm{S}^{221}$ motif and $\mathrm{N}^{155}$ function as the catalytic triad and oxyanion hole of NK, respectively [38,39]. These sites are critical for the protease hydrolysis process. Based on the crystal structure of Subtilisin E, a 3D structural model of NK was constructed [38]. It indicated that the overall active centers are negatively charged, suggesting that NK is more specific for positive-charged substrates. 3D model predicted that the mechanism of NK was induced by attacking of hydroxyl rich in catalytic environment and locating of $\mathrm{S}^{221}$ [38]. Site-directed mutagenesis and molecular dynamics 
simulation of a 3D model revealed that hydrogen bonds formed between residues, $\mathrm{S}^{33}, \mathrm{D}^{60}, \mathrm{~S}^{62}$, and $\mathrm{T}^{220}$ stabilize the transition state of the hydrolysis reaction. $\mathrm{S}^{125}, \mathrm{~L}^{126}$, and $\mathrm{G}^{127}$ serve as substrate binding sites. Three residues of $\mathrm{S} 3$ binding sites, $\mathrm{G}^{100}, \mathrm{~S}^{101}$, and $\mathrm{L}^{126}$ are responsible for fibrinolytic activity while they moderately affected substrate specificity [40].
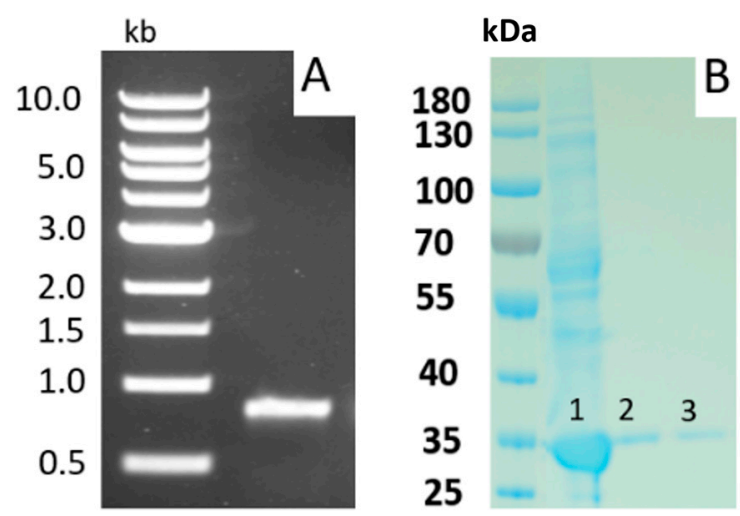

Figure 5. NK gene product and insoluble (inclusion-body) NK protein in Escherichia coli. (A) PCR-derived NK gene product from B. subtilis (natto); (B) Lane 1: NK protein present in crude medium extract; Lane 2 and 3: NK protein purified using a Ni-NTA (nickel-charged affinity nitrilotriacetic acid) column.

In addition to B. subtilis strains, researchers have isolated NK from marine organisms [41] and Pseudomonas sp. [42]. Sixteen NK gene sequences have been identified from various $B$. subtilis strains and their sequences are available in the NCBI GenBank. Amino acid sequence alignment of mature NKs demonstrates that they are highly homologous to each other; with some of the protein sequences possessing 100\% identity. For example, the amino acid sequence of AF368283.1 and JF921199.1 are 100\% identical. In addition, JN302072 and EF20828.1 also share the same amino acid sequences (Figure 6).

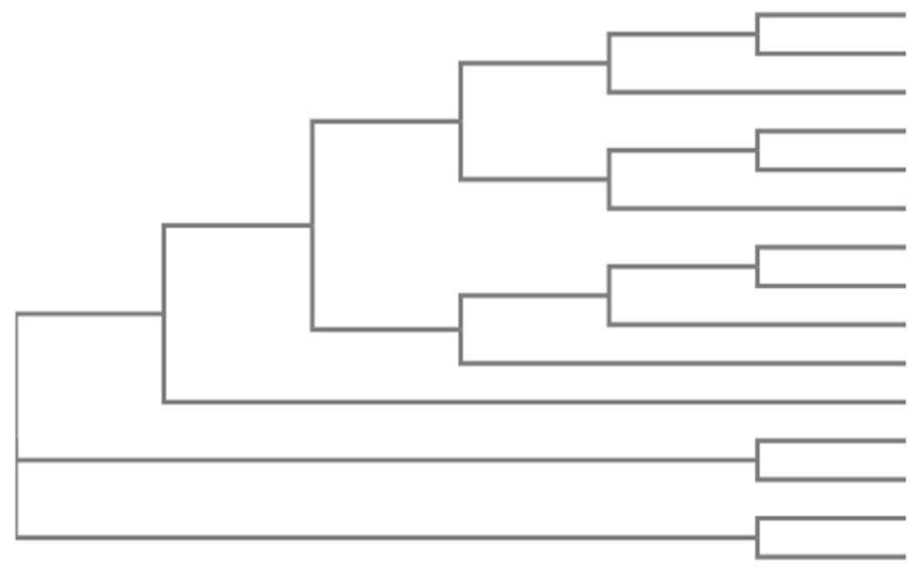

KJ205599.1 0.10685

DQ178658.1 0.02769

AJ314856.1 0.00629

KJ174338.1 0.00364

EF533986.10

KJ174339.1 0.00364

AY895162.1 0.00364

FJ376817.10

FJ407060.1 0.00633

AY219901.1 0.00203

KF734090.1 0.00716

EF208028.1 0.00364

JN392072.1 0.00364

JF921199.1 0

AF368283.10

Figure 6. Phylogeny of NK sequences. Predicted NK protein sequences were generated using DNA to PROTEIN software (available at: http://web.expasy.org/translate/). Sequence analysis, multiple sequence alignment, and phylogenetic analysis were conducted using ClustalW2 (available at: http:/ /www.ebi.ac.uk/Tools/msa/clustalw2/) software. A total of $16 \mathrm{NK}$ gene sequences were deposited in the NCBI Genbank. Fifteen mature protein sequences were subjected to a phylogenetic analysis. HM068963.1 is only represented by a partial sequence and as a result, was not included in the phylogenetic analysis. 


\section{Recombinant Nattokinase Production via Genetic Engineering}

In order to increase NK yields and simplify the downstream purification process, the NK gene has been cloned and expressed in various microbial host systems, including Escherichia coli [43-45], B. subtilis [46-48], and Lactococcus lactis [49]. E. coli has been extensively investigated as the easiest and cheapest host system to produce recombinant NK. Although NK can be expressed in E. coli, large amounts of recombinant protein aggregate results in the formation of insoluble and inactive inclusion bodies [43,44]. Recovery of bioactive NK from inclusion bodies is challenging. Most of the protein is lost during solubilization and refolding of the protein contained in the inclusion body is challenging. Liang et al. (2007) isolated an NK gene from Chinese douchi and fused it with a periplasmic secretion signal, PelB, and a native NK signal peptide [44]. Active NK was successfully expressed in E. coli, however, the fibrinolytic activity of the secreted, recombinant NK was considerably lower than NK isolated from natto. B. subtilis is also an attractive host for the production of recombinant NK since it has the capacity to produce secretory proteins. The -10 element (TACAAT) of the NK (PaprN) promoter was substituted with the consensus -10 region (TATAAT) and successfully enhanced NK expression $(643 \mathrm{mg} / \mathrm{L})$ in recombinant B. subtilis [50]. B. subtilis itself, however, produces a substantial number and quantity of native extracellular proteases which can hydrolyze recombinant proteins. In this regard, an extracellular-protease-deficient strain of B. subtilis has been used to produce enhanced levels of NK [51]. In that study, the NK gene was expressed under the control of the acoA promoter in B. subtilis WB800, a strain that lacks eight extracellular proteases. Although a high yield of $600 \mathrm{mg} / \mathrm{L}$ NK was achieved, the technique was not suitable for large-scale industrial application which requires the production of $\mathrm{g} / \mathrm{L}$ to be economically feasible.

The use of eukaryotic expression systems for the production of NK have also been explored. A modified Bac-to-Bac ${ }^{\circledR}$ baculovirus expression system was used to express and produce active soluble NK in Spodoptera frugiperda insect cells [52]. The high production costs and longer duration needed for expression ( $\sim$ two weeks) do not support the use of insect cells as an NK production system. A yeast expression system was also investigated as an NK production system [53]. In contrast to E. coli systems, yeast is able to perform post-translational modifications and possess the molecular machinery needed to fold recombinant proteins. The yeast, Pichia pastoris, in combination with a methanol-inducible promoter, has the ability to achieve a high density level during fermentation and can produce large quantities of recombinant protein. A low NK yield, however, was reported using a P. pastoris expression system; but the NK produced did exhibit fibrinolytic activity [53]. Methanol oxidation can induce cell death, and methanol also raises combustion concerns in large-scale industrial applications. Therefore, utilizing methanol to induce protein expression significantly limits the use of P. pastoris for the commercial production of NK.

\section{Plants as Potential Factories for Nattokinase Production}

Plant molecular farming (PMF), which utilizes plant systems for the production of recombinant human pharmaceutical proteins, has been investigated for over 30 years and is becoming an attractive alternative for the production of recombinant proteins [54-56]. Various difficulties-such as low yield, restrictive biosafety regulations, pollen contamination, and downstream processing challenges-have hindered its practical application $[55,57]$. The rapid development of genetic engineering technology, facilitated by bioinformatic, proteomic, and genomic advances are paving a pathway from the laboratory to the industrial production of recombinant proteins. In 2012, carrot-derived recombinant taliglucerase alfa (commercial name: ELELYSO ${ }^{\mathrm{TM}}$ ) became the first plant-based recombinant enzyme approved by the FDA to treat Gaucher's disease [58]. In 2014, the Ebola virus epidemic attracted scientific attention worldwide and the need to develop a vaccine. The fatality rate from Ebola was nearly $50 \%$, which resulted in approximately 11,000 deaths during that epidemic. No effective therapy was available for the treatment of Ebola, except ZMapp, a novel therapy utilizing a tobacco-expression system [59]. Seven Ebola patients achieved 100\% recovery after being administered ZMapp [55]. ZMapp was granted a fast-track clinical trial by the FDA in September, 2015. In light of the two 
highlighted successes (ELELUSO and ZMapp), researchers have vigorously investigated the use of plants as factories for the production of human pharmaceuticals. Currently, over 20 plant-derived recombinant therapeutic proteins are in clinical trials, and several have received FDA approval [55].

Nattokinase is an ideal candidate for PMF. One of the major concerns in using PMF to produce pharmaceutical proteins, however, is plant glycosylation. Glycosylation of proteins is a normal occurrence and is used to regulate protein function during plant growth and development [60]. Unfortunately, when plant-derived therapeutic proteins are administered by injection, plant-specific glycan residues may invoke unwanted side effects in patients, such as immunogenicity [61,62]. Plant products, however, do not induce an immunogenic response when they are consumed through the digestive system. Presently, people consume genetically modified food on a regular basis. Since NK is mainly administered orally, using transgenic plants to produce NK would not face problems associated with immunogenic responses, and may find greater acceptance due to the benefits of the recombinant protein on human health.

Using plant expression platforms for NK production could significantly reduce production costs (Figure 7). The expenses associated with the use of plant systems is very low, representing $0.1 \%$ to $10 \%$ of the cost associated with bacterial or other eukaryotic cell expression systems $[63,64]$. There are a variety of ways to produce NK in plant systems. A rapid method is the utilization of a transient expression system, which can produce high levels of recombinant protein within a relatively short period of time (four to seven days) [65-69]. Various virus-based transient vectors have been studied for use in PMF systems. The bean yellow dwarf virus (BeYDV)-based DNA replicon system, developed in the laboratory of Hugh Mason, is one of the well-known systems [70]. The BeYDV system produced $0.5 \mathrm{mg} / \mathrm{g}$ of Ebola antibody (ZMapp) in tobacco leaves [71]. In 2016, the BeYDV vector was optimized by modifying its $5^{\prime}$ and $3^{\prime}$ untranslated regions. Use of the optimized vector significantly enhanced the yield of recombinant protein $(1.8 \mathrm{mg} / \mathrm{L})$ in Nicotiana benthamiana leaves, which represented the highest yields of ZMapp ever reported [72]. Wang and Lauren (2014) successfully expressed NK in tobacco leaves utilizing the BeYDV system [73]. The plant-derived soluble NK produced using this system dissolved fibrin and blood clots in vitro. The high levels of recombinant NK produced in this system, however, also caused leaf necrosis. We have also expressed other blood-clot dissolving proteases, such as lumbrokinase, human tissue plasminogen activator (t-PA), and vampire bat plasminogen activator (DSPAs) in tobacco leaves [55]. In addition, all of the manufactured proteases caused plant cell death; resulting in leaf necrosis. The role of proteases in programmed cell death in animal cells is well known [74] and it is plausible that plant proteases may have a similar role.

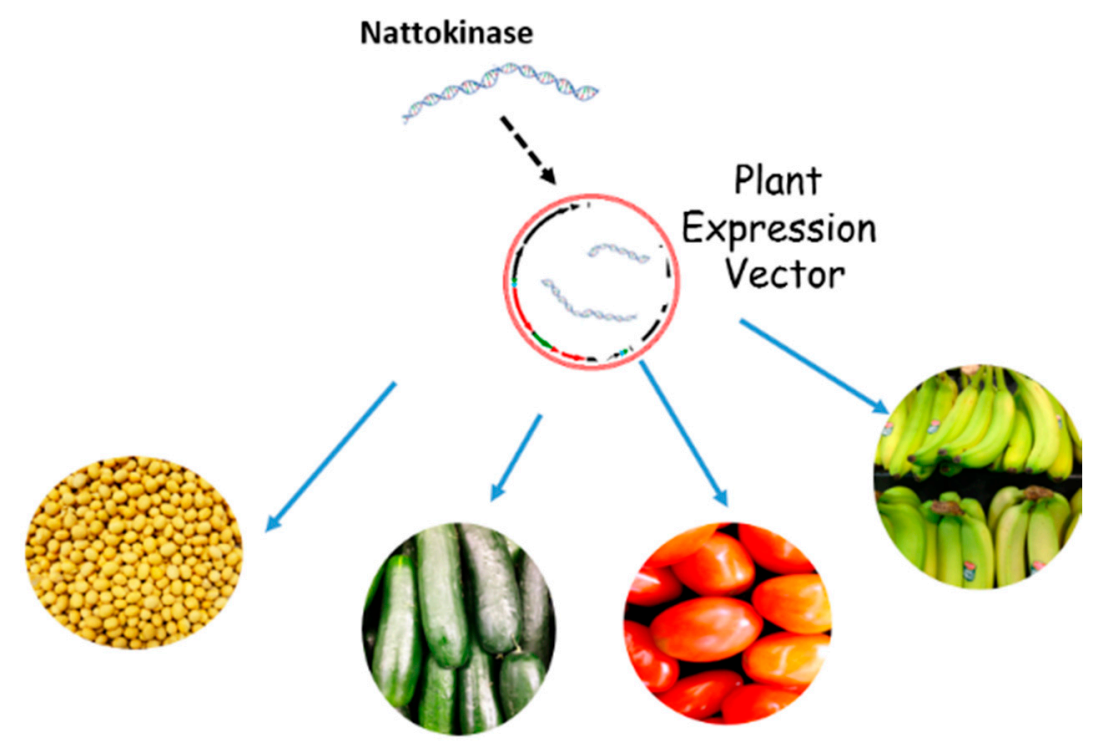

Figure 7. Plants as potential factories for NK production. 
Transient expression is relatively straightforward and scalable. Recombinant protein, however, has to be harvested in a timely manner; otherwise it is subject to proteolysis. Another approach to transient expression that overcomes the problem of proteolysis, is to express the recombinant protein-such as NK-in plant seeds. Recombinant proteins produced in this manner can be stored for long periods of time (up to three years), and are easy to harvest and transport. Seed-based systems have been investigated in rice [75], corn [76], Arabidopsis [77], tobacco [78], and soybean [79]. In transgenic rice seeds, the yield of recombinant human serum albumin is $10.58 \%$ of the total soluble protein (TSP) [75]. Cellobiohydrolase II (Cel6A) targeted to maize endosperm, represents $30 \%$ of seed TSP. Recombinant protein yield in soybean can reach $4 \%$ of TSP [80]. Since natural NK is produced from fermented soybeans, it represents an ideal platform for recombinant NK production. Soy formulations-such as soy milk, powder, or flour-are regularly fed to infants with little or no side effects. It is also possible to use soy formulation technology for NK application, which would require little to no downstream purification of recombinant NK from transgenic soybean seeds. We have expressed NK in tobacco seeds utilizing a seed-specific promoter (Phas). Seed-derived NK has also been demonstrated to dissolve fibrin (manuscript in preparation).

Downstream processing and purification of PMF-derived protein can be costly due to the presence of the large amounts of endogenous proteins, phenolic compounds, alkaline agents, lignin, and waxes produced by plants. Downstream processing costs have been estimated to represent $80 \%-90 \%$ of the total PMF production costs. NK, however, could be produced in edible plants, such as cucumber or tomato, with unprocessed plant material serving as the agent for oral delivery of the recombinant protein. This would eliminate expensive downstream extraction and purification costs. Another advantage of producing NK in plants is that plant cell walls, which are composed of complex carbohydrates, can potentially encapsulate the recombinant product and prolong enzyme activity as the protein passes through the gastrointestinal tract. As a result, NK activity would be protected before it enters into the circulatory system.

\section{Conclusions}

Nattokinase exhibits exceptionally potent fibrinolytic activity. Natto, a soybean product fermented by B. subtilis (natto) and rich in NK, has been served as a traditional food in Asia for hundreds of years and has recently garnered increased interest in Western medicine. Various animal and human trials have demonstrated that NK improves blood circulation and helps decrease the risk of a variety of cardiovascular diseases without producing any adverse side effects. The unpleasant odor and texture of natto limits its utilization as a dietary nutriment. Costly and complicated extraction and purification processes have inhibited the general use of NK as a nutraceutical. Currently, NK is sold as a dietary supplement in the United States, Canada, and Europe. It is available as a powder contained within a vegetable-based capsule. Ongoing advances in genetic engineering are providing a promising future for the economically-viable, large-scale production of high-quality NK using recombinant gene technology. Among the available expression systems (E. coli, yeast, and animal cell), plant expression represents a promising alternative system for the production of NK for direct consumption or further downstream processing and purification.

Acknowledgments: The research project was partially funded by the National Institute of General Medical Sciences of the National Institutes of Health (8P20GM103447) and the National Institute of Health-National Institute of Neurological Disorders and Stroke (R03NS095246).

Author Contributions: Yunqi Weng conceived the study and drafted the manuscript. Jian Yao analyzed data and helped write the paper. Sawyer Sparks participated in experiments and preparation of figures. Kevin Yueju Wang coordinated and helped write the manuscript. All authors read and approved the final manuscript.

Conflicts of Interest: The authors declare no conflict of interest. 


\section{Abbreviations}

$\begin{array}{ll}\text { NK } & \text { nattokinase } \\ \text { PMF } & \text { plant molecular farming } \\ \text { BeYDV } & \text { bean yellow dwarf virus } \\ \text { TSP } & \text { total soluble protein }\end{array}$

\section{References}

1. Sumi, H.; Hamada, H.; Tsushima, H.; Mihara, H.; Muraki, H. A novel fibrinolytic enzyme (nattokinase) in the vegetable cheese Natto; a typical and popular soybean food in the Japanese diet. Experientia 1987, 43, 1110-1111. [CrossRef] [PubMed]

2. Yatagai, C.; Maruyama, M.; Kawahara, T.; Sumi, H. Nattokinase promoted tissue plasminogen activator release from human cells. Pathophysiol. Haemost. Thromb. 2008, 36, 227-232. [CrossRef] [PubMed]

3. Fujita, M.; Hong, K.; Ito, Y.; Misawa, S.; Takeuchi, N.; Kariya, K.; Nishimuro, S. Transport of nattokinase across the rat intestinal tract. Biol. Pharm. Bull. 1995, 18, 1194-1196. [CrossRef] [PubMed]

4. Fujita, M.; Ohnishi, K.; Takaoka, S.; Ogasawara, K.; Fukuyama, R.; Nakamuta, H. Antihypertensive effects of continuous oral administration of nattokinase and its fragments in spontaneously hypertensive rats. Biol. Pharm. Bull. 2011, 34, 1696-1701. [CrossRef] [PubMed]

5. Nagata, C.; Wada, K.; Tamura, T.; Konishi, K.; Goto, Y.; Koda, S.; Kawachi, T.; Tsuji, M.; Nakamura, K. Dietary soy and natto intake and cardiovascular disease mortality in Japanese adults: The Takayama study. Am. J. Clin. Nutr. 2016. [CrossRef] [PubMed]

6. Dabbagh, F.; Negahdaripour, M.; Berenjian, A.; Behfar, A.; Mohammadi, F.; Zamani, M.; Irajie, C.; Ghasemi, Y. Nattokinase: Production and application. Appl. Microbiol. Biotechnol. 2014, 98, 9199-9206. [CrossRef] [PubMed]

7. Huang, Y.; Ding, S.; Liu, M.; Gao, C.; Yang, J.; Zhang, X.; Ding, B. Ultrasmall and anionic starch nanospheres: Formation and vitro thrombolytic behavior study. Carbohydr. Polym. 2013, 96, 426-434. [CrossRef] [PubMed]

8. Sumi, H.; Hamada, H.; Nakanishi, K.; Hiratani, H. Enhancement of the fibrinolytic activity in plasma by oral administration of nattokinase. Acta Haematol. 1990, 84, 139-143. [CrossRef] [PubMed]

9. Jensen, G.S.; Lenninger, M.; Ero, M.P.; Benson, K.F. Consumption of nattokinase is associated with reduced blood pressure and von Willebrand factor, a cardiovascular risk marker: Results from a randomized, double-blind, placebo-controlled, multicenter North American clinical trial. Integr. Blood Press. Control. 2016, 9, 95-104. [CrossRef] [PubMed]

10. Kurosawa, Y.; Nirengi, S.; Homma, T.; Esaki, K.; Ohta, M.; Clark, J.F.; Hamaoka, T. A single-dose of oral nattokinase potentiates thrombolysis and anti-coagulation profiles. Sci. Rep. 2015, 5, 11601. [CrossRef] [PubMed]

11. Lampe, B.J.; English, J.C. Toxicological assessment of nattokinase derived from Bacillus subtilis var. natto. Food Chem. Toxicol. 2016, 88, 87-99. [CrossRef] [PubMed]

12. Suzuki, Y.; Kondo, K.; Matsumoto, Y.; Zhao, B.-Q.; Otsuguro, K.; Maeda, T.; Tsukamoto, Y.; Urano, T.; Umemura, K. Dietary supplementation of fermented soybean, natto, suppresses intimal thickening and modulates the lysis of mural thrombi after endothelial injury in rat femoral artery. Life Sci. 2003, 73, 1289-1298. [CrossRef]

13. Jang, J.-Y.; Kim, T.-S.; Cai, J.; Kim, J.; Kim, Y.; Shin, K.; Kim, K.-S.; Park, S.K.; Lee, S.-P.; Choi, E.-K.; et al. Nattokinase improves blood flow by inhibiting platelet aggregation and thrombus formation. Lab. Anim. Res. 2013, 29, 221-225. [CrossRef] [PubMed]

14. Xu, J.; Du, M.; Yang, X.; Chen, Q.; Chen, H.; Lin, D.H. Thrombolytic effects in vivo of nattokinase in a carrageenan-induced rat model of thrombosis. Acta Haematol. 2014, 132, 247-253. [CrossRef] [PubMed]

15. Hsia, C.-H.; Shen, M.-C.; Lin, J.-S.; Wen, Y.-K.; Hwang, K.-L.; Cham, T.-M.; Yang, N.-C. Nattokinase decreases plasma levels of fibrinogen, factor VII, and factor VIII in human subjects. Nutr. Res. 2009, 29, 190-196. [CrossRef] [PubMed]

16. Ero, M.P.; Ng, C.M.; Mihailovski, T.; Harvey, N.R.; Lewis, B.H. A pilot study on the serum pharmacokinetics of nattokinase in humans following a single, oral, daily dose. Altern. Ther. Health Med. 2013, 19, 16-19. [PubMed] 
17. Chang, Y.-Y.; Liu, J.-S.; Lai, S.-L.; Wu, H.-S.; Lan, M.-Y. Cerebellar hemorrhage provoked by combined use of nattokinase and aspirin in a patient with cerebral microbleeds. Intern. Med. 2008, 47, 467-469. [CrossRef] [PubMed]

18. Fadl, N.N.; Ahmed, H.H.; Booles, H.F.; Sayed, A.H. Serrapeptase and nattokinase intervention for relieving Alzheimer's disease pathophysiology in rat model. Hum. Exp. Toxicol. 2013, 32, 721-735. [CrossRef] [PubMed]

19. Dogné, J.M.; Hanson, J.; de Leval, X.; Pratico, D.; Pace-Asciak, C.R.; Drion, P.; Pirotte, B.; Ruan, K.H. From the design to the clinical application of thromboxane modulators. Curr. Pharm. Des. 2006, 12, 903-923. [CrossRef] [PubMed]

20. Ibe, S.; Kumada, K.; Yoshida, K.; Otobe, K. Natto (fermented soybean) extract extends the adult lifespan of Caenorhabditis elegans. Biosci. Biotechnol. Biochem. 2013, 77, 392-394. [CrossRef] [PubMed]

21. Inatsu, Y.; Nakamura, N.; Yuriko, Y.; Fushimi, T.; Watanasiritum, L.; Kawamoto, S. Characterization of Bacillus subtilis strains in Thua nao, a traditional fermented soybean food in northern Thailand. Lett. Appl. Microbiol. 2006, 43, 237-242. [CrossRef] [PubMed]

22. Peng, Y.; Huang, Q.; Zhang, R.-H.; Zhang, Y.-Z. Purification and characterization of a fibrinolytic enzyme produced by Bacillus amyloliquefaciens DC-4 screened from douche, a traditional Chinese soybean food. Comp. Biochem. Physiol. B Biochem. Mol. Biol. 2003, 134, 45-52. [CrossRef]

23. Kim, W.; Choi, K.; Kim, Y.; Park, H.; Choi, J.; Lee, Y.; Oh, H.; Kwon, I.; Lee, S. Purification and characterization of a fibrinolytic enzyme produced from Bacillus sp. strain CK 11-4 screened from Chungkook-Jang. Appl. Environ. Microbiol. 1996, 62, 2482-2488. [PubMed]

24. Fujita, M.; Nomura, K.; Hong, K.; Ito, Y.; Asada, A.; Nishimuro, S. Purification and characterization of a strong fibrinolytic enzyme (nattokinase) in the vegetable cheese natto, a popular soybean fermented food in Japan. Biochem. Biophys. Res. Commun. 1993, 197, 1340-1347. [CrossRef] [PubMed]

25. Maeda, H.; Mizutani, O.; Yamagata, Y.; Ichishima, E.; Nakajima, T. Alkaline-resistance model of subtilisin ALP I, a novel alkaline subtilisin. J. Biochem. 2001, 129, 675-682. [CrossRef] [PubMed]

26. Tuan, N.A.; Thuan, D.H.T.; Tam, T.T.M.; Huong, N.T. Determination the optimum fermentation in obtaining nattokinase by Bacillus subtilis natto. Int. J. Innov. Appl. Stud. 2015, 13, 663-668.

27. Tuan, N.A.; Huong, N.T. Optimization of the fermentation medium to receive the highest biomass yield by Bacillus subtilis natto and the initial test of nattokinase yield. IOSR J. Eng. 2014, 4, 35-40.

28. Ku, T.W.; Tsai, R.L.; Pan, T.M. A simple and cost-saving approach to optimize the production of subtilisin NAT by submerged cultivation of Bacillus subtilis natto. J. Agric. Food Chem. 2009, 57, 292-296. [CrossRef] [PubMed]

29. Wang, S.-L.; Chen, H.-J.; Liang, T.-W.; Lin, Y.-D. A novel nattokinase produced by Pseudomonas sp. TKU015 using shrimp shells as substrate. Process Biochem. 2009, 44, 70-76. [CrossRef]

30. Wang, S.L.; Wu, Y.Y.; Liang, T.W. Purification and biochemical characterization of a nattokinase by conversion of shrimp shell with Bacillus subtilis TKU007. N. Biotechnol. 2011, 28, 196-202. [CrossRef] [PubMed]

31. Berenjian, A.; Mahanama, R.; Kavanagh, J.; Dehghani, F.; Ghasemi, Y. Nattokinase production: Medium components and feeding strategy studies. Chem. Ind. Chem. Eng. 2014, 20, 541-547. [CrossRef]

32. Deepak, V.; Kalishwaralal, K.; Ramkumarpandian, S.; Babu, S.V.; Senthilkumar, S.R.; Sangiliyandi, G. Optimization of media composition for nattokinase production by Bacillus subtilis using response surface methodology. Bioresour. Technol. 2008, 99, 8170-8174. [CrossRef] [PubMed]

33. Rasagnya, P.S.; Vangalapati, M. Studies on optimization of process parameters for nattokinase production by Bacillus subtilis NCIM 2724 and purification by liquid-liquid extraction. Int. J. Innov. Res. Sci. Eng. Technol. 2013, 2, 4516-4521.

34. Garg, R.; Thorat, B.N. Nattokinase purification by three phase partitioning and impact of t-butanol on freeze drying. Sep. Purif. Technol. 2014, 131, 19-26. [CrossRef]

35. Ito, K. Grain and legume allergy. Chem. Immunol. Allergy 2015, 101, 145-151. [PubMed]

36. Nakamura, T.; Yamagata, Y.; Ichishima, E. Nucleotide sequence of the subtilisin NAT gene, aprN, of Bacillus subtilis (natto). Biosci. Biotechnol. Biochem. 1992, 56, 1869-1871. [CrossRef] [PubMed]

37. Peng, Y.; Yang, X.; Zhang, Y. Microbial fibrinolytic enzymes: An overview of source, production, properties, and thrombolytic activity in vivo. Appl. Microbiol. Biotechnol. 2005, 69, 126-132. [CrossRef] [PubMed] 
38. Zheng, Z.-L.; Zuo, Z.-Y.; Liu, Z.-G.; Tsai, K.-C.; Liu, A.-F.; Zou, G.-L. Construction of a 3D model of nattokinase, a novel fibrinolytic enzyme from Bacillus natto: A novel nucleophilic catalytic mechanism for nattokinase. J. Mol. Graph. Model. 2005, 23, 373-380. [CrossRef] [PubMed]

39. Zheng, Z.-L.; Ye, M.-Q.; Zuo, Z.-Y.; Liu, Z.-G.; Tai, K.-C.; Zou, G.-L. Probing the importance of hydrogen bonds in the active site of the subtilisin nattokinase by site-directed mutagenesis and molecular dynamics simulation. Biochem. J. 2006, 395, 509-515. [CrossRef] [PubMed]

40. Wu, S.; Feng, C.; Zhong, J.; Huan, L. Roles of s3 site residues of nattokinase on its activity and substrate specificity. J. Biochem. 2007, 142, 357-364. [CrossRef] [PubMed]

41. Mahajan, P.M.; Nayak, S.; Lele, S.S. Fibrinolytic enzyme from newly isolated marine bacterium Bacillus subtilis ICTF-1: Media optimization, purification and characterization. J. Biosci. Bioeng. 2012, 113, 307-314. [CrossRef] [PubMed]

42. Chandrasekaran, S.D.; Vaithilingam, M.; Shanker, R.; Kumar, S.; Thiyur, S.; Babu, V.; Selvakumar, J.N.; Prakash, S. Exploring the in vitro thrombolytic activity of nattokinase from a New Strain Pseudomonas aeruginosa CMSS. Jundishapur J. Microbiol. 2015, 8, e23567. [CrossRef] [PubMed]

43. Ni, H.; Guo, P.-C.; Jiang, W.-L.; Fan, X.-M.; Luo, X.-Y.; Li, H.-H. Expression of nattokinase in Escherichia coli and renaturation of its inclusion body. J. Biotechnol. 2016, 231, 65-71. [CrossRef] [PubMed]

44. Liang, X.; Jia, S.; Sun, Y.; Chen, M.; Chen, X.; Zhong, J.; Huan, L. Secretory expression of nattokinase from Bacillus subtilis YF38 in Escherichia coli. Mol. Biotechnol. 2007, 37, 187-194. [CrossRef] [PubMed]

45. Chiang, C.-J.; Chen, H.-C.; Chao, Y.-P.; Tzen, J.-T. Efficient system of artificial oil bodies for functional expression and purification of recombinant nattokinase in Escherichia coli. J. Agric. Food Chem. 2005, 53, 4799-4804. [CrossRef] [PubMed]

46. Chen, P.-T.; Chiang, C.-J.; Chao, Y.-P. Strategy to approach stable production of recombinant nattokinase in Bacillus subtilis. Biotechnol. Prog. 2007, 23, 808-813. [CrossRef] [PubMed]

47. Kwon, E.-Y.; Kim, K.-M.; Kim, M.-K.; Lee, I.-Y.; Kim, B.-S. Production of nattokinase by high cell density fed-batch culture of Bacillus subtilis. Bioprocess Biosyst. Eng. 2011, 34, 789-793. [CrossRef] [PubMed]

48. Chen, P.T.; Chiang, C.J.; Chao, Y.P. Medium optimization for the production of recombinant nattokinase by Bacillus subtilis using response surface methodology. Biotechnol. Prog. 2007, 23, 1327-1332. [CrossRef] [PubMed]

49. Liang, X.; Zhang, L.; Zhong, J.; Huan, L. Secretory expression of a heterologous nattokinase in Lactococcus lactis. Appl. Microbiol. Biotechnol. 2007, 75, 95-101. [CrossRef] [PubMed]

50. Wu, S.-M.; Feng, C.; Zhong, J.; Huan, L.-D. Enhanced production of recombinant nattokinase in Bacillus subtilis by promoter optimization. World J. Microbiol. Biotechnol. 2011, 27, 99-106. [CrossRef]

51. Nguyen, T.T.; Quyen, T.D.; Le, H.T. Cloning and enhancing production of a detergent- and organic-solventresistant nattokinase from Bacillus subtilis VTCC-DVN-12-01 by using an eight-protease-gene-deficient Bacillus subtilis WB800. Microb. Cell Fact. 2013, 12, 79. [CrossRef] [PubMed]

52. Li, X.; Wang, X.; Xiong, S.; Zhang, J.; Cai, L.; Yang, Y. Expression and purification of recombinant nattokinase in Spodoptera frugiperda cells. Biotechnol. Lett. 2007, 29, 1459-1464. [CrossRef] [PubMed]

53. Luo, L.; Huang, Z.; Pan, L.; Yang, R.; Liang, S. Expression of nattokinase gene in yeast Pichia pastoris. J. South China Univ. Technol. 2003, 31, 1-4.

54. Shahid, N.; Daniell, H. Plant-based oral vaccines against zoonotic and non-zoonotic diseases. Plant Biotechnol. J. 2016, 14, 2079-2099. [CrossRef] [PubMed]

55. Yao, J.; Weng, Y.; Dickey, A.; Wang, K.Y. Plants as factories for human pharmaceuticals: Applications and Challenges. Int. J. Mol. Sci. 2015, 16, 28549-28565. [CrossRef] [PubMed]

56. Hiwasa-Tanase, K.; Ezura, H. Molecular Breeding to Create Optimized Crops: From Genetic Manipulation to Potential Applications in Plant Factories. Front Plant Sci. 2016, 7, 539. [CrossRef] [PubMed]

57. Buyel, J.F.; Twyman, R.M.; Fischer, R. Extraction and downstream processing of plant-derived recombinant proteins. Biotechnol. Adv. 2015, 33, 902-913. [CrossRef] [PubMed]

58. Fox, J.L. First plant-made biologic approved. Nat. Biotechnol. 2012, 30, 472. [CrossRef]

59. Arntzen, C. Plant-made pharmaceuticals: From "Edible Vaccines" to Ebola therapeutics. Plant Biotechnol. 2015, 13, 1013-1016. [CrossRef] [PubMed]

60. Loos, A.; Steinkellner, H. Plant glyco-biotechnology on the way to synthetic biology. Front Plant Sci. 2014, 5, 523. [CrossRef] [PubMed] 
61. Tschofen, M.; Knopp, D.; Hood, E.; Stöger, E. Plant molecular farming: Much more than medicines. Annu. Rev. Anal. Chem. 2016, 9, 271-294. [CrossRef] [PubMed]

62. Bosch, D.; Castilho, A.; Loos, A.; Schots, A.; Steinkellner, H. N-glycosylation of plant-produced recombinant proteins. Curr. Pharm. Des. 2013, 19, 5503-5512. [CrossRef] [PubMed]

63. Daniell, H.; Streatfield, S.J.; Rybicki, E.P. Advances in molecular farming: Key technologies, scaled up production and lead targets. Plant Biotechnol. J. 2015, 13, 1011-1012. [CrossRef] [PubMed]

64. Spök, A.; Karner, S. Plant Molecular Farming: Opportunities and Challenges; JRC Technical Report EUR 23383 EN; Office for Official Publications of the European Communities: Kopstal, Luxembourg, 2008.

65. Drake, P.M.; Szeto, T.H.; Paul, M.J.; Teh, A.Y.; Ma, J.K. Recombinant biologic products versus nutraceuticals from plants-A regulatory choice? Br. J. Clin. Pharmacol. 2017, 83, 82-87. [CrossRef] [PubMed]

66. De Martinis, D.; Rybicki, E.P.; Fujiyama, K.; Franconi, R.; Benvenuto, E. Editorial: Plant Molecular Farming: Fast, scalable, cheap, sustainable. Front. Plant Sci. 2016, 7, 1148. [CrossRef] [PubMed]

67. Sainsbury, F.; Lomonossoff, G.P. Transient expressions of synthetic biology in plants. Curr. Opin. Plant Biol. 2014, 19, 1-7. [CrossRef] [PubMed]

68. Peyret, H.; Lomonossoff, G.P. When plant virology met Agrobacterium: The rise of the deconstructed clones. Plant Biotechnol. J. 2015, 13, 1121-1135. [CrossRef] [PubMed]

69. Catrice, E.V.; Sainsbury, F. Assembly and purification of polyomavirus-like particles from plants. Mol. Biotechnol. 2015, 57, 904-913. [CrossRef] [PubMed]

70. Huang, Z.; Phoolcharoen, W.; Lai, H.; Piensook, K.; Cardineau, G.; Zeitlin, L.; Whaley, K.J.; Arntzen, C.J.; Mason, H.S.; Chen, Q. High-level rapid production of full-size monoclonal antibodies in plants by a single-vector DNA replicon system. Biotechnol. Bioeng. 2010, 106, 9-17. [CrossRef] [PubMed]

71. Qiu, X.; Wong, G.; Audet, J.; Bello, A.; Fernando, L.; Alimonti, J.B.; Fausther-Bovendo, H.; Wei, H.; Aviles, J.; Hiatt, E.; et al. Reversion of advanced Ebola virus disease in nonhuman primates with ZMapp. Nature 2014, 514, 47-53. [CrossRef] [PubMed]

72. Diamos, A.G.; Rosenthal, S.H.; Mason, H.S. $5^{\prime}$ and $3^{\prime}$ Untranslated regions strongly enhance performance of geminiviral replicons in Nicotiana benthamiana leaves. Front. Plant Sci. 2016, 7, 200. [CrossRef] [PubMed]

73. Wang, K.; Tull, L. Expression of blood clot-dissolving proteins in transgenic plant. FASEB J. 2014, 28 (Suppl. LB852), 1.

74. Duprez, L.; Wirawan, E.; Vanden Berghe, T.; Vandenabeele, P. Major cell death pathways at a glance. Microbes Infect. 2009, 11, 1050-1062. [CrossRef] [PubMed]

75. He, Y.; Ning, T.; Xie, T.; Qiu, Q.; Zhang, L.; Sun, Y.; Jiang, D.; Fu, K.; Yin, F.; Zhang, W.; et al. Large-scale production of functional human serum albumin from transgenic rice seeds. Proc. Natl. Acad. Sci. USA 2011, 108, 19078-19083. [CrossRef] [PubMed]

76. Devaiah, S.P.; Requesens, D.V.; Chang, Y.K.; Hood, K.R.; Flory, A.; Howard, J.A.; Hood, E.E. Heterologous expression of cellobiohydrolase II (Cel6A) in maize endosperm. Transgenic Res. 2013, 22, 477-488. [CrossRef] [PubMed]

77. De Jaeger, G.; Scheffer, S.; Jacobs, A.; Zambre, M.; Zobell, O.; Goossens, A.; Depicker, A.; Angenon, G. Boosting heterologous protein production in transgenic dicotyledonous seeds using Phaseolus vulgaris regulatory sequences. Nat. Biotechnol. 2002, 20, 1265-1268. [CrossRef] [PubMed]

78. Scheller, J.; Leps, M.; Conrad, U. Forcing single-chain variable fragment production in tobacco seeds by fusion to elastin-like polypeptides. Plant Biotechnol. J. 2006, 4, 243-249. [CrossRef] [PubMed]

79. da Cunha, N.B.; Murad, A.M.; Vianna, G.R.; Coelho, C.; Rech, E.L. Expression and characterization of recombinant molecules in transgenic soybean. Curr. Pharm. Des. 2013, 19, 5553-5563. [CrossRef] [PubMed]

80. Bost, K.; Piller, K. Protein expression systems: Why soybean seeds? In Soybean-Molecular Aspects of Breeding; Sudaric, A., Ed.; InTech: Rijeka, Croatia, 2011; pp. 1-18.

(C) 2017 by the authors. Licensee MDPI, Basel, Switzerland. This article is an open access article distributed under the terms and conditions of the Creative Commons Attribution (CC BY) license (http:/ / creativecommons.org/licenses/by/4.0/). 